\title{
Electrochemical exfoliation-streamline method for synthesis of nitrogen doped graphene
}

\author{
Roberts Olins ${ }^{1,2 *}$, \\ Peteris Lesnicenoks ${ }^{1,2}$, \\ Janis Kleperis ${ }^{1}$, \\ Ainars Knoks ${ }^{1}$, \\ Ingars Lukosevics ${ }^{1}$ \\ ${ }^{1}$ Institute of Solid State Physics, \\ University of Latvia, \\ 8 Kengaraga Street, \\ 1063 Riga, Latvia \\ ${ }^{2}$ Faculty of Material Science \\ and Applied Chemistry, \\ Riga Technical University, \\ 14/24 Azenes Street, \\ 1048 Riga, Latvia
}

\begin{abstract}
Graphene was discovered in the early 21 st century, but has already proven itself in many applications - energy, medicine, electronics, food and sports, and more. Functionalization of nanostructured carbon materials with both non-metallic and metallic atoms is possible in various ways, imparting enhanced or new properties to the starting material, even catalytic activity. A method of electrochemical exfoliation was used to obtain the graphene sheets and simultaneously functionalize them with nitrogen. To ensure $\mathrm{N}$-doping the process is done in $\mathrm{a} \mathrm{NaN}_{3}$ electrolyte solution which provides less quantity of oxygen groups that tend to block defect sites on the graphene, compared with such solvents as $\mathrm{NaNO}_{2}$. Two graphite electrodes are inserted into the electrolyte and a pulse power of $0-10 \mathrm{~V}$ is applied. The solution containing the obtained material is filtered through a $0.1 \mu \mathrm{m}$ filter and dried. The material is characterized using SEM, $\mathrm{XRD}$ and XPS. In the XPS characterization graphene oxide is used as a reference material.
\end{abstract}

Keywords: nitrogen-doped graphene, sodium azide, sodium nitrite, electrochemical exfoliation

\section{INTRODUCTION}

The goal of the paper is to explain the electrochemical exfoliation process for the synthesis of $\mathrm{N}$-functionalized graphene as well as the characterization of the acquired material.

Beyond its unique set of physico-chemical properties, graphene can be considered as a robust, atomic scale scaffold from which other 2D materials can be derived through the replacement/attachment of foreign atoms and functional groups [1-3]. Among the possible doping agents, nitrogen (N)

\footnotetext{
*Corresponding author. Email: roberts.olins@cfi.lu.lv
}

has drawn a considerable amount of attention because its atomic radius is comparable to that of carbon and contains five valence electrons available to form strong covalent bonds. The conjugation between the nitrogen lone-pair electrons and the graphene $\pi$-system modifies graphene physical and chemical properties. The substitution of carbon atoms by nitrogen ones influences the atomic charge distribution on the graphene scaffold and creates 'active sites' thus significantly increasing the electrochemical activity of nitrogen-doped graphene, known as $\mathrm{N}$-graphene (NG) [4].

Graphene, as a 2D carbon nanomaterial in which sp2 hybridized carbon atoms are aligned in 
a honeycomb lattice, is a relatively new material with a wide range of applications due to its chemical stability, electric and thermal conductivity and large surface area [3-7]. Recent studies reveal that substitutional doping of graphene with heteroatoms $\mathrm{N}$ can tailor its electrical conductivity, wettability and electro-active surface area to facilitate charge-transfer and electrolyte-electrode interactions, and may give rise to its electrochemical performance [月, 8].

As mentioned before, the functionalization of graphene improves upon its base qualities. In the case of nitrogen doping resolve at least three types of $\mathrm{C}-\mathrm{N}$ bonds (defect sites) can form during the functionalization process [7, 9]: quaternary $\mathrm{N}$ (or graphitic $\mathrm{N}$ ), pyridinic $\mathrm{N}$ and pyrrolic $\mathrm{N}$ (Fig. 1) [10]. Usually, pyridinic $\mathrm{N}$ bonds with two $\mathrm{C}$ atoms at the edges or defects of graphene contribute one $\mathrm{p}$ electron to the $\pi$ system. Pyrrolic $\mathrm{N}$ refers to $\mathrm{N}$ atoms that contribute two $p$ electrons to the $\pi$ system, although unnecessarily bond into the five-membered ring, as in pyrrole. Quaternary $\mathrm{N}$ is the $\mathrm{N}$ atoms that substitute for $\mathrm{C}$ atoms in a hexagonal ring. In these nitrogen types, pyridinic $\mathrm{N}$ and quaternary $\mathrm{N}$ are $\mathrm{sp} 2$ hybridized and pyrrolic- $\mathrm{N}$ is $\mathrm{sp} 3$ hybridized [2, 3, 6, 10].

Nitrogen doped graphene can further be used in batteries, sensors, supercapacitors, fuel cells and more [2,6, 㠶.

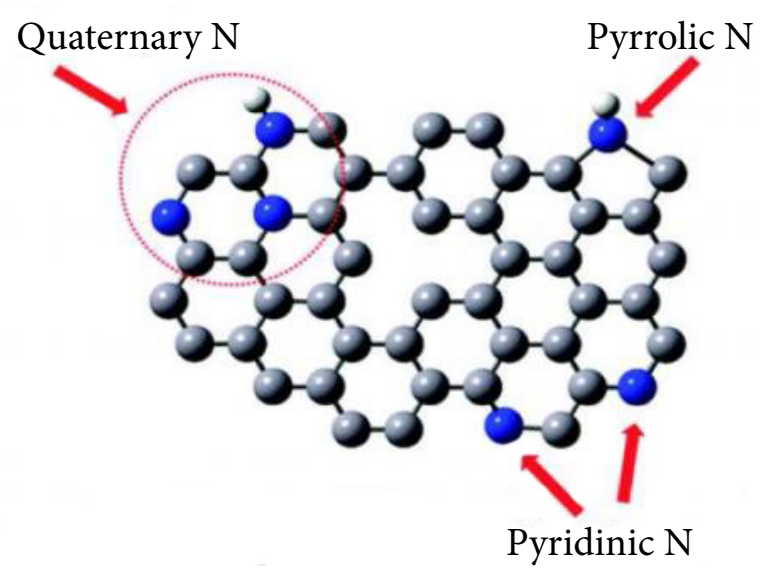

Fig. 1. Three bonding configurations of $\mathrm{N}$-doped graphene

\section{EXPERIMENTAL}

Commercially available chemicals have been used. High-purity graphite rods (Alfa Aesar, 99.9995\%), commercially available chemicals (analytical grade)- $\mathrm{NaN}_{3}, \mathrm{NaNO}_{2}, \mathrm{HNO}_{3}$ and 2-propanol were used as supplied without additional purification. Distilled water was used for electrolyte preparation and washing.

Electrochemical exfoliation of graphite was carried out in a $800 \mathrm{ml}$ beaker using two highpurity graphite rods (HOPG) and a potentiostat (212, ISSP) situated as shown in Fig. 2. The synthesis procedure was carried out in a pulse mode of electrolysis-polarization of electrode by +10 and $0 \mathrm{~V}$ (both throughout $30 \mathrm{~s}$ ) with multiple changing of polarization potential. The synthesis process was carried out in $27 \mathrm{~h}$ maximum time. One molar aqueous solution of $\mathrm{NaN}_{3}$ and $\mathrm{NaNO}_{2}$ was used as electrolyte with different procedures and results. In the case of $\mathrm{NaNO}_{2}$ about $75 \mathrm{ml}$ of $\mathrm{HNO}_{3}$ was added at the beginning of the process. The obtained dispersion of the graphene material was stirred using ultrasound treatment in a UP200St ultrasonic processor (hielsher) for $1 \mathrm{~min}$ and then filtered through series of filters with different pore sizes $(0.45,0.2$ and $0.1 \mu \mathrm{m})$. During filtration the material was rinsed thoroughly with distilled water and dried in an oven at $50^{\circ} \mathrm{C}$.

For XPS measurements an ESCALAB Xi, Thermo Fisher spectroscope was used. For SEM images a Helios 5 UX, Thermo Fisher Scientific microscope was used. For XRD measurements a MiniFlex 600, Rigaku spectroscope was used.

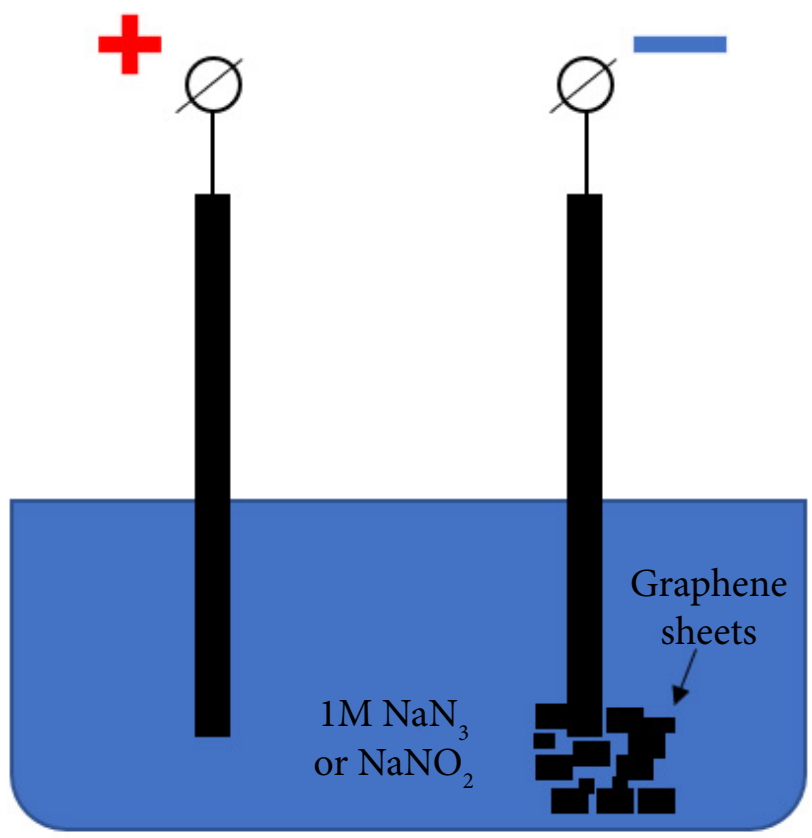

Fig. 2. Schematic representation of the synthesis equipment 
The dry material was then wrapped in filter paper and washed with a mixture of water and 2-propanol using a Soxhlet extractor therefore getting rid of the unwanted leftover synthesis solution. After letting the process run for $15 \mathrm{~h}$, the material was dried and, if needed, transferred to the appropriate solvent and dispersed using ultrasound treatment for $1 \mathrm{~min}$.

\section{RESULTS AND DISCUSSION}

During the exfoliation process a change in the colour of the electrolyte from colourless to grey, then to black, could be observed, indicating that graphene sheets were created during the process [3].
During the electrolysis process azide decomposes into $\mathrm{Na}^{+}$and $\mathrm{N}_{3}{ }^{-}$ions as well as sodium nitrite decomposes into $\mathrm{Na}^{+}$and $\mathrm{NO}_{2}^{-}$ions. The $\mathrm{N}_{3}{ }^{-}$ion changes further: $\mathrm{N}_{3}^{-} \rightarrow 3 / 2 \mathrm{~N}_{2}+\mathrm{e}^{-}$and in water $\mathrm{N}_{3}{ }^{-}+3 \mathrm{H}_{2} \mathrm{O}+2 \mathrm{e}^{-} \rightarrow \mathrm{N}_{2}+\mathrm{NH}_{3}+3 \mathrm{OH}^{-}$. The nitrite ion reacts with water creating nitric acid and nitric oxide: $\mathrm{NO}_{2}{ }^{-}+\mathrm{H}_{2} \mathrm{O} \rightarrow \mathrm{HNO}_{3}+\mathrm{NO}$ and in further reactions $\mathrm{N}_{2}$ and $\mathrm{NH}_{3}$ are created. The $\mathrm{N}_{3}{ }^{-}$and $\mathrm{NO}_{2}{ }^{-}$ions intercalate in the graphite layers, and when they decompose, they simultaneously split the graphite layers and functionalize the graphene [3].

Figures 3,4 and 5 show the X-ray photoelectron spectroscopy (XPS) measurements of graphene

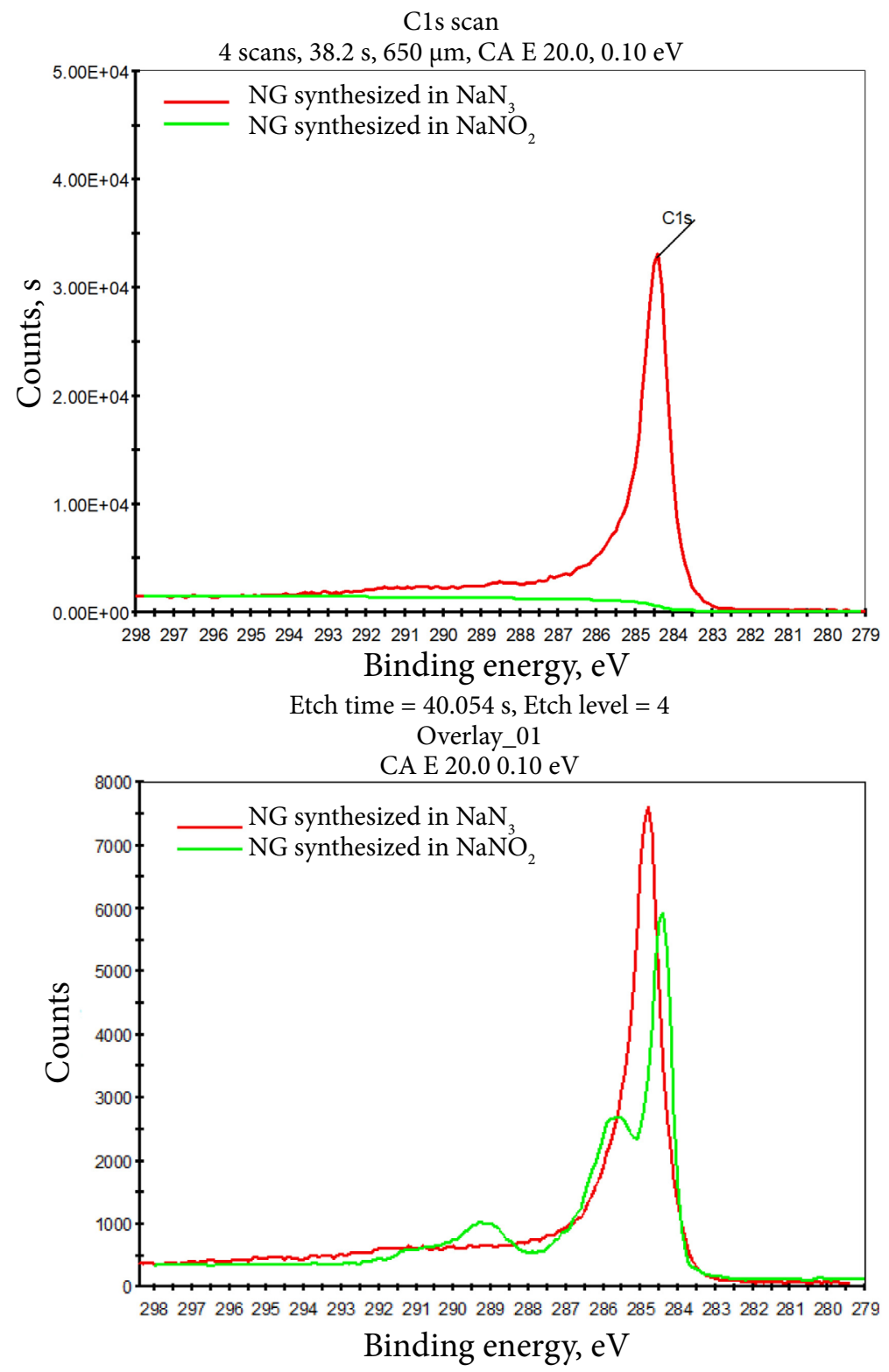

Fig. 3. XPS (a) $\mathrm{C} 1 \mathrm{~s}$ scan of $\mathrm{GO}$ synthesized using modified Hummer's method and (b) overlay of $\mathrm{NG}$ synthesized in $\mathrm{NaN3}$ and $\mathrm{NaNO}_{2}$ 


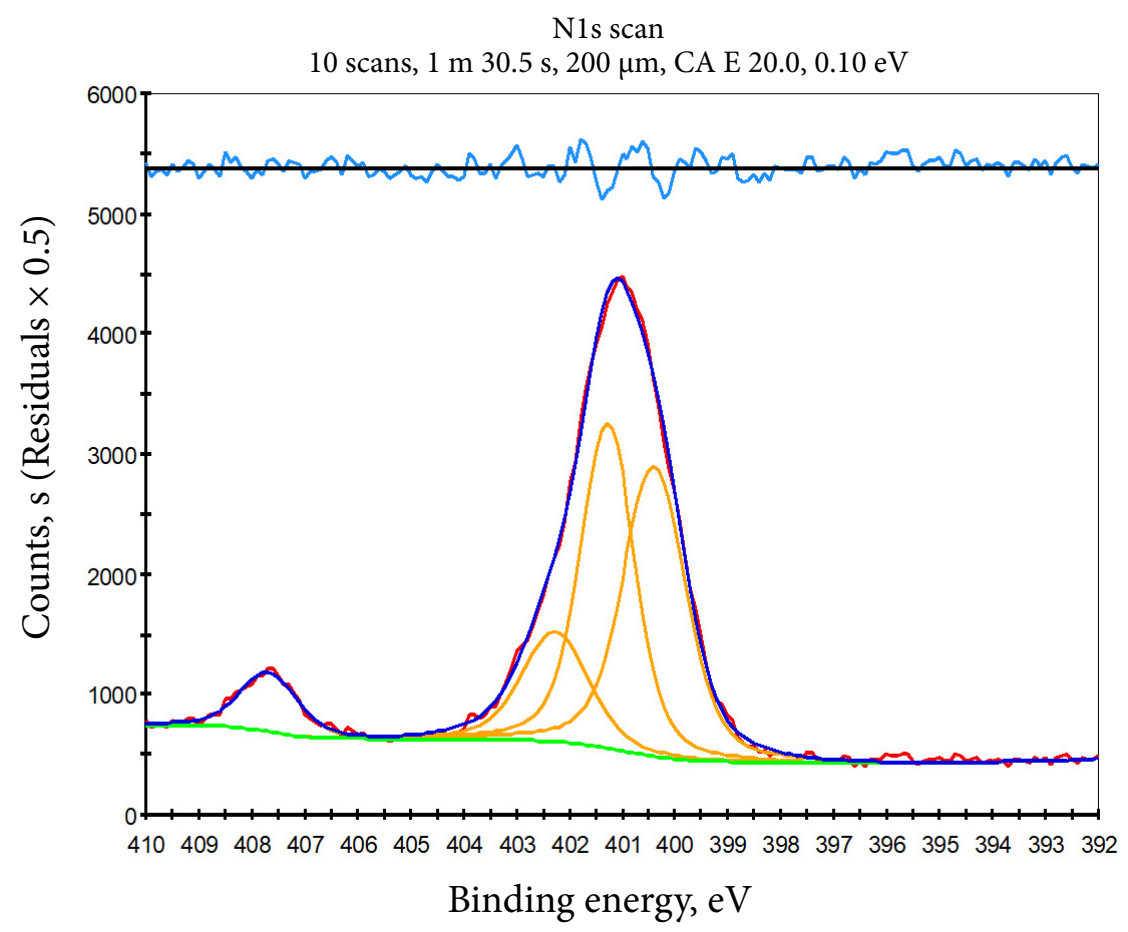

Fig. 4. XPS spectra of NG synthesized using $\mathrm{NaN}_{3}$

oxide GO synthesized by a modified Hummer's method [11] and NG from electrochemical exfoliation in $\mathrm{NaN}_{3}$ and $\mathrm{NaNO}_{2}$, respectively.

XPS is the standard quantitative spectroscopy technique to study the nitrogen doping effect in graphene. In the XPS spectrum of $\mathrm{N}$-graphene, at about 400 and $284 \mathrm{eV}$ the peaks appear that resemble $\mathrm{N} 1 \mathrm{~s}$ and $\mathrm{C} 1 \mathrm{~s}$, respectively. The ratio of peak intensity between $\mathrm{N} 1 \mathrm{~s}$ and $\mathrm{C} 1 \mathrm{~s}$ is employed to determine the nitrogen content in $\mathrm{N}$-graphene. In Fig. 3 we can examine GO to determine that graphene has indeed been produced considering

N1s scan \#009|_lielaks_BE_|apgabals_|4_ 15 scans, $3 \mathrm{~m} 45.7 \mathrm{~s}, 650 \mu \mathrm{m}, \mathrm{CA}$ E 20.0, $0.10 \mathrm{eV}$

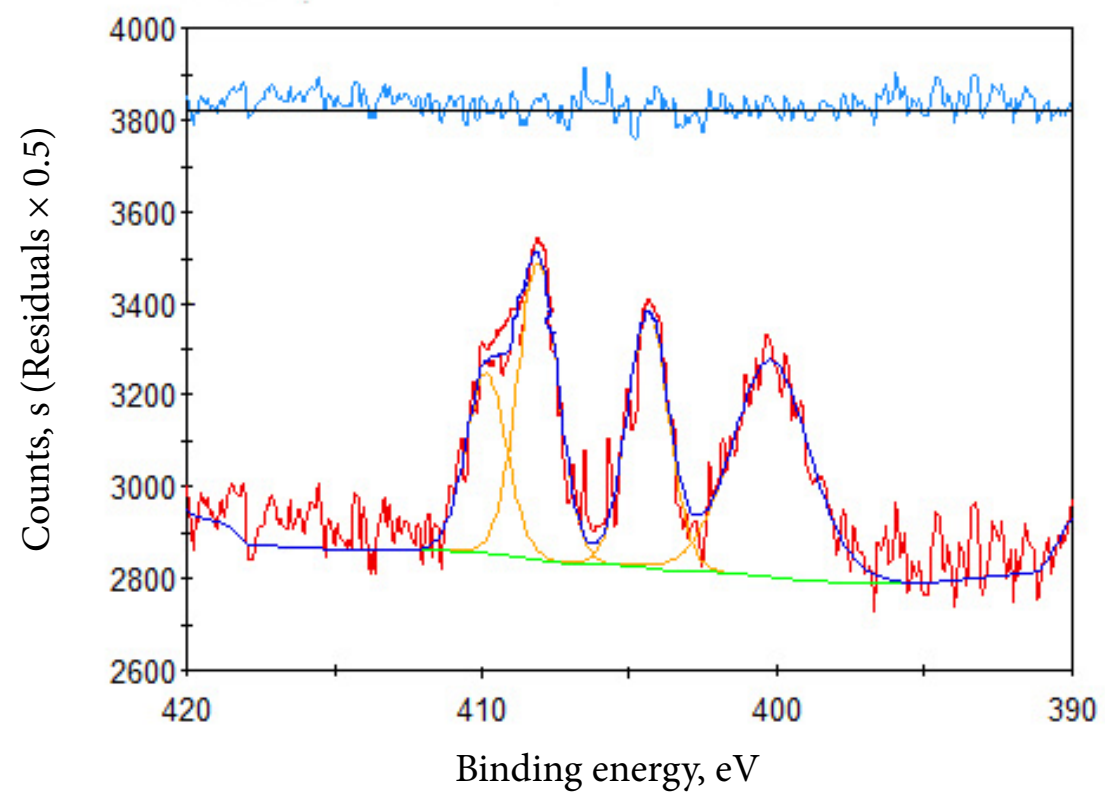

Fig. 5. XPS spectra of $\mathrm{NG}$ synthesized using $\mathrm{NaNO}_{2}$ 
that graphitic carbon (Csp2 hybridized) can be viewed $(284-285 \mathrm{eV})$ in all of the scans [7, 8, 12].

The N1s spectrum is used to determine the nitrogen configurations. Usually the N1s spectrum can be deconvoluted to several individual peaks that are allocated to different $\mathrm{C}-\mathrm{N}$ bonds: pyridinic- $\mathrm{N}(400 \mathrm{eV})$, pyrrolic-N (401-402 eV), quaternary- $\mathrm{N}(402-403 \mathrm{eV})$ and $\mathrm{N}$-oxides of pyridinic $\mathrm{N}$ $(408-410 \mathrm{eV})[4-6,8,9,12,13]$. As a consequence of the sample being charged, the readings could change, as we see in Fig. 4, where all of the peaks have moved.

Figure 6 shows the X-ray spectroscopy (XRD) measurements of the solution after the electro- chemical exfoliation in $\mathrm{NaN}_{3}$. We found that the solution contained mainly $\mathrm{NaHCO}_{3}$ [14] and we can assume that all $\mathrm{NaN}_{3}$ has dissociated. We can assume that the $\mathrm{C}^{4+}$ ion presence tells us that the $\mathrm{C}-\mathrm{C}$ bonds in graphene have been split and the lack of nitrogen in the solution tells us that there is a big likelihood that $\mathrm{C}-\mathrm{N}$ bonds have been created.

Figure 7 shows the XRD measurements of graphene that was synthesized using $\mathrm{NaNO}_{2}$ electrolyte solution. We can see a peak at around 26-28 degrees and that is consistent with the peak of nitrogen-doped graphene [5, 6, 12, 13.

Figure 8 is a scanning electron microscope (SEM) image taken of nitrogen doped graphene

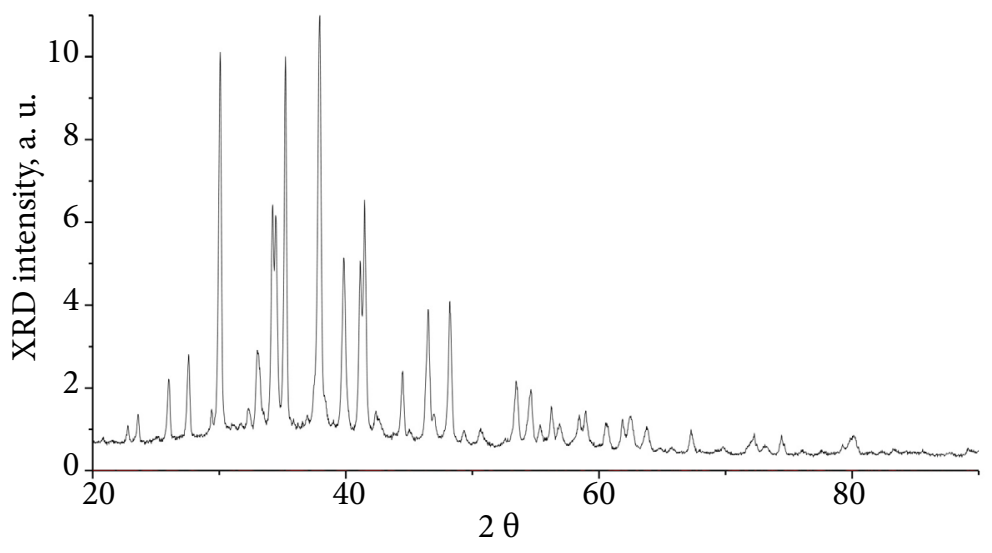

Fig. 6. XRD spectra of $\mathrm{NaN}_{3}$ solution after synthesis

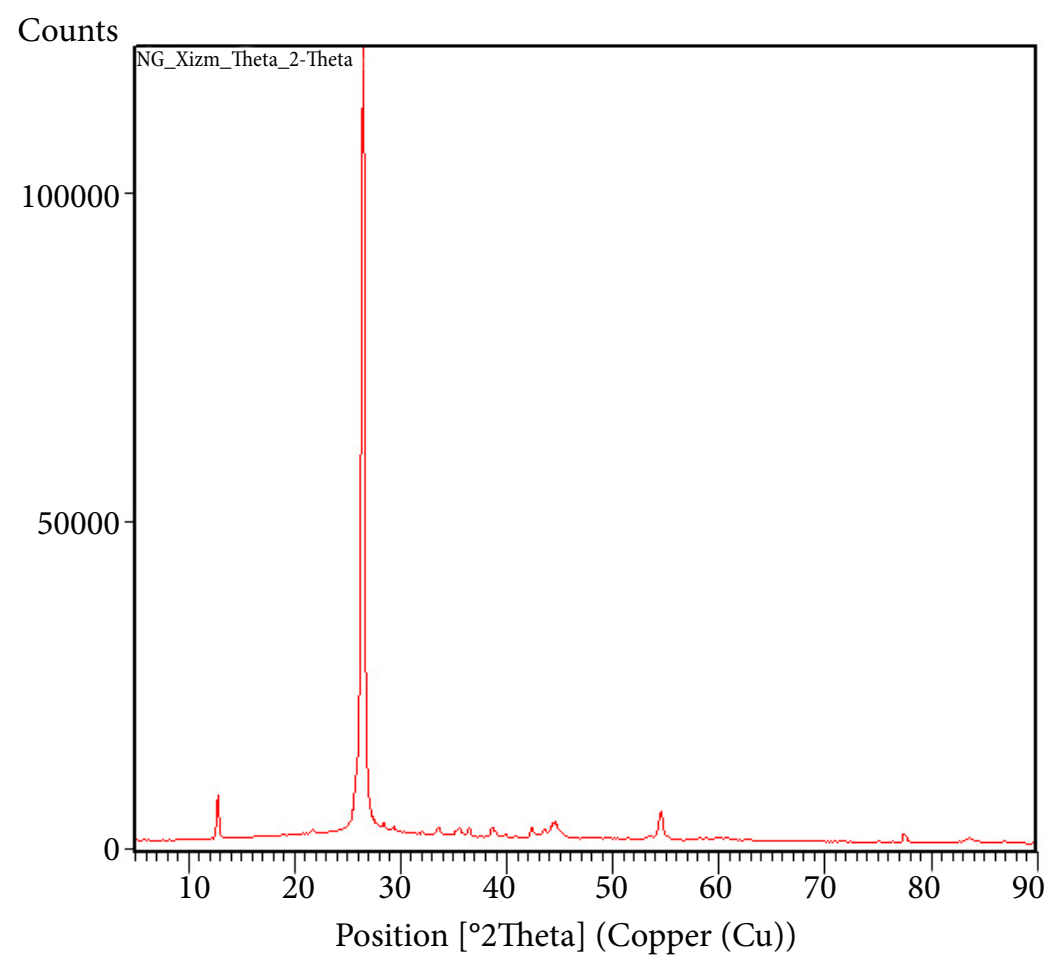

Fig. 7. XRD spectra of $\mathrm{NG}$ synthesized in $\mathrm{NaNO}_{2}$ 

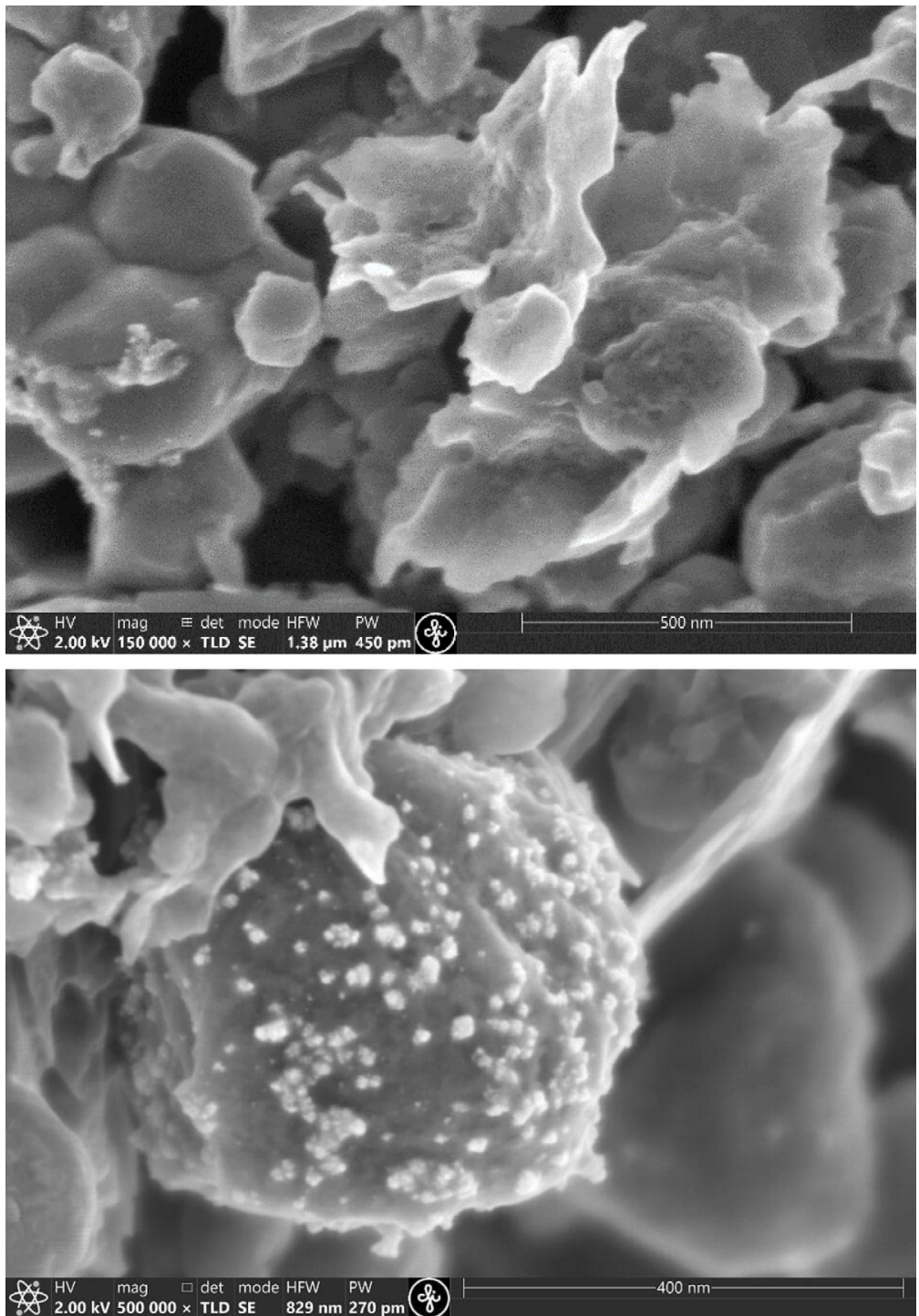

Fig. 8. SEM images of $N G$ synthesized in $\mathrm{NaN}_{3}$ : (a) single sheet, (b) particles smaller than $10 \mathrm{~nm}$

that has been synthesized using $\mathrm{NaN}_{3}$. We can see the single layer of graphene that has been formed (a) which confirms that the graphite has been exfoliated into graphene.

Furthermore, we see small particles of graphene at the size of $10 \mathrm{~nm}$ and even barely visible particles as small as $1 \mathrm{~nm}$ (b), in the image they can be seen as small white spots on a bigger graphene piece.

Figure 9 is a SEM image taken of nitrogen doped graphene that has been synthesized using $\mathrm{NaNO}_{2}$. In the image (a) we see $50 \mathrm{~nm}$ graphene sheets that have not come apart fully. In the image (b) we see a similar situation, only the sheets are smaller at around $3 \mathrm{~nm}$ if we look at the smallest sheets.

In conclusion, the process and results of electrochemical preparation of multilayer graphene func- tionalized with nitrogen (N-MLG) via exfoliation of graphite electrodes in the presence of azide and nitrite anions in a pulse mode of electrolysis have been proven. Sodium azide and nitrite provide not only exfoliation of graphite into graphene but also simultaneously functionalize the graphene with nitrogen ions as a part of azide and nitrite ion decomposition. The X-ray diffractometer analysis confirmed that all of the nitrogen had left the solution after synthesis and $\mathrm{C}^{4+}$ ion was present which indicated that the nitrogen probably had intercalated into the graphene sheets. The X-ray photoelectron spectroscope confirmed the nitrogen groups in the material and GO was used as a reference material. The scanning electron microscope images confirmed that few-layer graphene was acquired as well even though it could not have been 

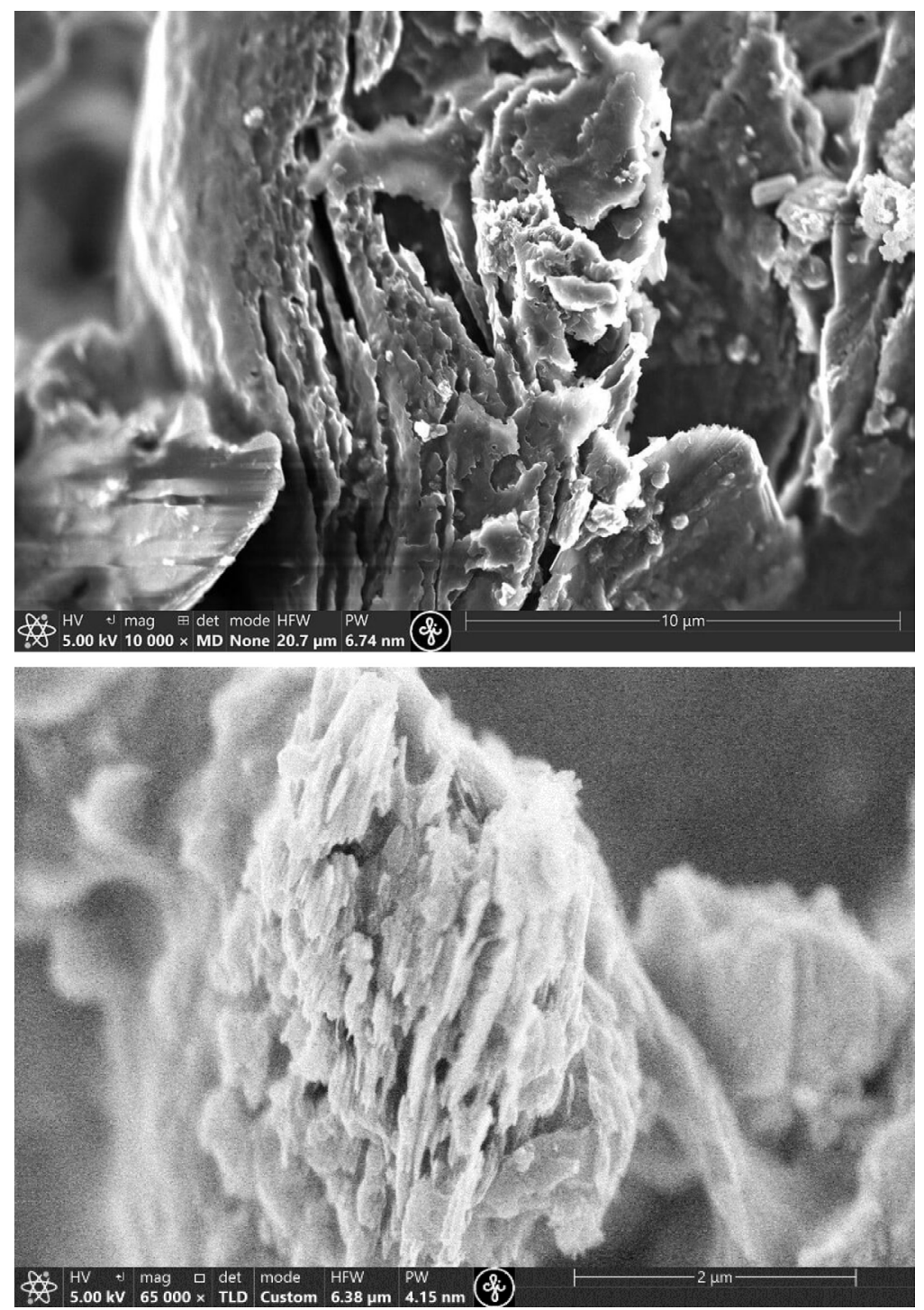

Fig. 9. SEM images of $\mathrm{NG}$ synthesized in $\mathrm{NaNO}_{2}$ : (a) sheet stack at a size $\sim 50 \mathrm{~nm}$, (b) sheet stacks at a size of $\sim 3 \mathrm{~nm}$

filtered due to its small size. Further studies are needed to improve upon the synthesis method.

\section{ACKNOWLEDGEMENTS}

The authors gratefully acknowledge financial support from the Latvian Council of Science, Project LZP FLPP No. LZP-2018/1-0194, and the Institute of Solid State Physics, University of Latvia that as the Center of Excellence has received funding from the European Union's Horizon 2020 Framework Programme H2020-WIDESPREAD01-2026-2017-TeamingPhase2 under Grant Agreement No. 739508, Project CAMART²

Received 11 December 2020 Accepted 3 January 2021

\section{References}

1. L. Li, B. Yu, T. You, Biosens. Bioelectron., 74, 263 (2015).

2. M. Kaur, M. Kaur, V. K. Sharma, Adv. Colloid Interface Sci., 259, 44 (2018).

3. O. Ustavytska, Y. Kurys, V. Koshechko, V. Pokhodenko, Nanoscale Res. Lett., 12(1), 175 (2017).

4. N. Bundaleska, J. Henriques, M. Ambrashev, et al., Sci. Rep., 8(1), 12595 (2018).

5. H. Xu, L. Ma, Z. Jin, J. Energy Chem., 27(1), 146 (2018).

6. R. Ma, X. Ren, B. Y. Xia, et al., Nano Res., 9(3), 808 (2016).

7. T. Kuila, S. Bose, A. K. Mishra, P. Khanra, N. H. Kim, J. H. Lee, Prog. Mater. Sci., 57(7), 1061 (2012).

8. Y. Yang, W. Shi, R. Zhang, et al., Electrochim. Acta, 204, 100 (2016). 
9. B. Xiong, Y. Zhou, Y. Zhao, et al., Carbon N. Y., 52, 181 (2013).

10. R. Yadav, C. K. Dixit, J. Sci. Adv. Mater. Devices, 2(2), 141 (2017).

11. N. I.Zaaba, K. L. Foo, U. Hashim, S. J. Tan, W. W. Liu, C. H. Voon, Procedia Eng., 184, 469-477 (2017).

12. C. Maddi, F. Bourquard, V. Barnier, et al., Sci. Rep., 8(1), 3247 (2018).

13. J. C. Carrillo-Rodríguez, I. L. Alonso-Lemus, A. A. Siller-Ceniceros, et al., Int. J. Hydrogen Energy, 42(51), 30383 (2017).

14. B. Dutcher, M. Fang, B. Leonard, et al., J. Phys. Chem. C, 115(31), 15532 (2011).
Roberts Olins, Peteris Lesnicenoks, Janis Kleperis, Ainars Knoks, Ingars Lukosevics

ELEKTROCHEMINĖ EKSFOLIACIJA KAIP PATOGUS BŪDAS AZOTU DOPUOTO GRAFENO SINTEZEI

Santrauka

Elektrocheminès eksfoliacijos būdas panaudotas sintezuojant grafeno lakštus ir kartu dopuojant juos azotu. Darbe aprašomos šios sintezès sąlygos, užtikrinančios mažesnio kiekio deguonies turinčių funkcinių grupių susidarymą. Susintetintos medžiagos charakterizuotos skenuojančios elektroninès mikroskopijos, rentgeno spindulių difrakcijos ir fotoelektroninès spektroskopijos metodais. 